\title{
Comparison of effect of nifedipine, labetalol and methyldopa in treatment of hypertension in pregnancy in a tertiary care government hospital
}

\author{
Vibhuti Thakur ${ }^{1 *}$, Ashok Thakur ${ }^{2}$, Satish Saroshe ${ }^{3}$
}

${ }^{1}$ Department of Obstetrics \& Gynaecology, M.G.M Medical College, Indore, India
${ }^{2}$ Department of Medicine, M.G.M Medical College, Indore, India
${ }^{3}$ Department of Community Medicine, M.G.M Medical College, Indore, India

Received: 05 December 2015

Accepted: 07 December 2015

*Correspondence:

Dr. Vibhuti Thakur,

E-mail: drvibhuti01@gmail.com

Copyright: (c) the author(s), publisher and licensee Medip Academy. This is an open-access article distributed under the terms of the Creative Commons Attribution Non-Commercial License, which permits unrestricted non-commercial use, distribution, and reproduction in any medium, provided the original work is properly cited.

\begin{abstract}
Background: To know the incidence \& demographic aspects of hypertensive disorders in pregnancy and to compare effect of nifedipine, labetalol, methyldopa on various aspects of PIH such as control of BP, proteinuria, gestational age on admission \& of delivery and maternal \& perinatal outcome.

Methods: Study was conducted in M.Y. Hospital, Indore for one year of period. Three groups each of 50 pts were given nifedipine, labetalol, and methyldopa. Groups were compared on basis of age, residence, parity, control of BP, proteinuria, gestational age of delivery maternal complication \&perinatal outcome.

Results: maximum patients were from younger age group and mostly are primigravida. Fall in systolic \& diastolic BP is significant in all 3 groups. Incidence of decrease in albuminuria is max in labetalol group. Incidence of LSCS is maximum in nifedipine group. No statistically significant difference in three groups regarding foetal outcome.

Conclusions: All three drugs are safe \& effective drug in treatment of PIH. Labetalol is more effective in reducing albuminuria as compared to nifedipine \& methyldopa.
\end{abstract}

Keywords: Preeclampsia, Antihypertensive drugs

\section{INTRODUCTION}

Hypertensive disorders complicate $5-10 \%$ of all pregnancies and together they form one member of deadly triad, along with hemorrhage \& infection that contribute greatly to maternal morbidity and mortality rates. ${ }^{1}$ Pregnancy induced hypertension includes a group of hypertensive disorders developed due to gravid state after 20 weeks of pregnancy. Preeclampsia may be mild or severe. HELLP (Hemolysis, Elevated liver enzymes, Low platelet counts) syndrome is a complication of severe preeclampsia/eclampsia. ${ }^{2}$
Incidence of Eclampsia in the developed countries is about 1 in 2000 deliveries $^{3}$ as compared to developing countries $^{4-6}$ where it varies from 1 in 100 to 1 in 1700 . Preeclampsia/eclampsia probably accounts for more than 50,000 maternal deaths worldwide each year. ${ }^{7}$

The most recent report from the International Society for the Study of Hypertension in Pregnancy (ISSHP) in 2001 has taken cognizance of other classifications, viz. the Australian Society for the Study of Hypertension in Pregnancy (ASSHP), National High Blood Pressure Programme (NHBEP) in the US, the older ISSHP classification, World Health Organization (WHO) and the 
Canadian Hypertension Society. The ISSHP classification is currently widely accepted and includes the following categories: (i) pre-Eclampsia; (ii) chronic hypertension (essential or secondary); (iii) pre-Eclampsia superimposed on chronic hypertension; and (iv) gestational hypertension.

\section{Gestational hypertension}

- Systolic B.P. $\geq 140$ or diastolic B.P. $\geq 90 \mathrm{~mm} \mathrm{Hg}$ for the first time during pregnancy.

- No proteinuria.

- B.P. returns to normal before 12 weeks postpartum.

- Final diagnosis made only postpartum.

\section{Preeclampsia- minimum criteria}

- $\quad$ B.P. $\geq 140 / 90 \mathrm{~mm} \mathrm{Hg}$ after 20 weeks gestation

- Proteinuria $\geq 300 \mathrm{mg} / 24 \mathrm{hrs}$ or $\geq 1+$ dipstick.

\section{Increased certainty of preeclampsia}

- $\quad$ B.P. $\geq 160 / 110 \mathrm{~mm} \mathrm{Hg}$

- $\quad$ Proteinuria $\geq 2 \mathrm{~g} / 24 \mathrm{hr}$ or $\geq 2+$ dipstick

- Sr. creatinine $>1.2 \mathrm{mg} / \mathrm{dl}$ unless known to be previously elevated.

- Platelets $<100000 / \mu \mathrm{L}$

- Microangiopathic hemolysis- increased LDH

- Elevated AST or ALT.

- Persistent headache or other cerebral or visual disturbance

- Persistent epigastric pain.

Eclampsia Seizures that cannot be attributed to other cause in a women with preeclampsia.

\section{Superimposed preeclampsia on chronic hypertension}

- New onset proteinuria $\geq 300 \mathrm{mg} / 24 \mathrm{hr}$ in hypertensive women but no proteinuria before 20 weeks gestation.

A sudden increase in proteinuria or B.P. or platelet count $<100000 / \mu \mathrm{L}$ in women with hypertension and proteinuria before 20 weeks gestation.

\section{Chronic hypertension}

- $\quad$ B.P. $\geq 140 / 90 \mathrm{~mm} \mathrm{Hg}$ before pregnancy or diagnose before 20 weeks gestation not attributable to gestational trophoblastic disease.

\section{Or}

- Hypertension first diagnosed after 20 weeks and persistent after 12 weeks postpartum.

The present study was carried out with the following aims and objectives:
1. To know the incidence \& demographic aspects of hypertensive disorders in pregnancy.

2. Comparative study of the effect of Labetalol, Nifedepine and methyldopa in control of hypertension in PIH.

3. Comparative study of effects of Labetalol, Nifedipine and Methyldopa drugs on proteinuria

4. To compare the gestational age on admission and gestational age of delivery in patients of PIH treated with Labetalol, Nifedipine and Methyldopa.

5. To study maternal outcome in cases of hypertension in pregnancy treated with Labetalol, Nifedipine and Methyldopa.

6. To study perinatal outcomes in cases of hypertension in pregnancy treated with labetalol, nifedipine and methyldopa.

\section{METHODS}

Maharaja Yashwantrao Hospital, Indore is a referral centre which provides level III care to its patients. This study was carried out in the Department of Obstetrics \& Gynaecology of this institution in which Labetalol, Nifedipine and Methyldopa will be administered to the patients with pregnancy induced hypertension as a mode of conservative management to improve fetal maturity thereby increasing chances of fetal viability. The study will be carried out over a period of 12 months from October 2010to September 2011. A total 50 patients in each group will be included in the study.

\section{Study design}

The trial will be conducted as a comparative prospective randomized case study. The controls will not be taken as on ethical grounds it will not be possible to give placebo therapy to patients with severe hypertension in pregnancy.

\section{Inclusion criteria}

- All patients with hypertension whose two blood pressure recordings are $\geq 140 / 90 \mathrm{~mm} \mathrm{Hg}$ more than 6 hours apart.

- Patients with severe hypertension (Systolic blood pressure $\geq 169 \mathrm{~mm} \mathrm{Hg}$ or Diastolic blood pressure $\geq 110 \mathrm{~mm} \mathrm{Hg}$ ) will be included in the study.

- $\quad$ Patients with gestational age from 27 weeks up to 36 weeks will be included in the trial.

- Patients who are sure of their LMP with regular cycles or those with first trimester ultrasound will be taken in the study.

\section{Exclusion criteria}

- Patients with severe preeclampsia (Systolic blood pressure $\geq 160 \mathrm{~mm} \mathrm{Hg}$ or Diastolic blood pressure $\geq 110 \mathrm{~mm} \mathrm{Hg}$ ), with albuminuria of more than $2+$ will be excluded from the study. 
Edema of face and hands will be considered more significant as compared to ankle edema.

- Patients receiving more than one antihypertensive drug since admission will be excluded from study.

- Patients with IUD since admission.

Inpatients will be monitored daily for blood pressure, urine albumin, FHS and mean arterial pressure.

Patients will be monitored with routine investigations, fundus examinations, renal profile and coagulation profile. Ultrasonography with colour Doppler will be done at the time of admission and repeated as required.

Aim of antihypertensive therapy in the management of $\mathrm{PIH}$ is to prevent complications due to hypertension while prolonging the course of pregnancy. It is generally indicated that severe hypertension require antihypertensive therapy. But in mild and moderate hypertension the need for antihypertensive therapy is to prevent progression to severe hypertension. The commonly used antihypertensive drugs in pregnancy are nifedipine, methyldopa, labetalol and hydralazine. ${ }^{8}$

Labetalol will be started with an initial dose of $100 \mathrm{mg}$ $\mathrm{BD}$ and the dose will be increased as required. The maximum dose of $100 \mathrm{mg}$ TDS will be given. Nifedipine will be started with an initial dose of $10 \mathrm{mg}$ BD and the dose will be increased upto $20 \mathrm{mg}$ TDS. Methyldopa will be given in a dose of $250 \mathrm{mg} \mathrm{BD}$ and/or a max of $500 \mathrm{mg}$ TDS.

All patients with live fetus at entry will be included. Conservative treatment will be attempted to attain fetal lung maturity and to avoid maternal complications. Therapy will be abandoned if maternal or fetal complications occur.

The treatment in any of the drugs will not be prolonged beyond 37 completed weeks.

After labor, the placenta was inspected, weighed, and any infarcts, calcifications or anomalies will be noted.

The mother as well as the baby will be followed up for a period of at least one week.

The gestational age at delivery, birth weight, sex, Apgar score, and heart rate will be recorded as well as the need for admission to and the time spent in the special care nursery. The development of respiratory distress syndrome or jaundice will be noted. Blood glucose measurements of the neonates will be done if clinically indicated. The mother will be followed up till the duration her blood pressure comes to baseline level.

\section{RESULTS}

Total 150 patients were enrolled for this study. They were divided into three groups of 50 cases each. Groups are labelled as-

Group A-Nifedipine Group B-Labetalol Group Cmethyldopa

Maximum cases in all three groups belong to age of 21 to 25 years and most cases were primigravida. Since MYH is government hospital, most of patients from rural community and hence illiterate too.

Table 1: Distribution of cases according to Age group.

\begin{tabular}{|c|c|c|c|c|c|c|}
\hline \multirow[t]{2}{*}{ Age } & \multicolumn{2}{|c|}{$\begin{array}{l}\text { Group A } \\
\text { Nifedipine }\end{array}$} & \multicolumn{2}{|c|}{$\begin{array}{l}\text { Group B } \\
\text { Labetalol }\end{array}$} & \multicolumn{2}{|c|}{$\begin{array}{l}\text { Group C } \\
\text { Methyldopa }\end{array}$} \\
\hline & No. & $\%$ & No. & $\%$ & No. & $\%$ \\
\hline $\begin{array}{l}\text { Upto } \\
20 \\
\text { years }\end{array}$ & 16 & $32 \%$ & 12 & $24 \%$ & 9 & $18 \%$ \\
\hline $\begin{array}{l}21-25 \\
\text { years }\end{array}$ & 19 & $38 \%$ & 22 & $44 \%$ & 22 & $44 \%$ \\
\hline $\begin{array}{l}26-30 \\
\text { years }\end{array}$ & 10 & $20 \%$ & 12 & $24 \%$ & 14 & $28 \%$ \\
\hline $\begin{array}{l}>\mathbf{3 0} \\
\text { years }\end{array}$ & 5 & $10 \%$ & 4 & $8 \%$ & 5 & $10 \%$ \\
\hline Total & 50 & 100.00 & 50 & 100.00 & 50 & 100.00 \\
\hline
\end{tabular}

Table 2: Distribution of cases according to parity.

\begin{tabular}{|lllllll|}
\hline \multirow{2}{*}{ Parity } & \multicolumn{2}{c}{ Group A } & \multicolumn{2}{c|}{ Group B } & \multicolumn{2}{c|}{ Group C } \\
\cline { 2 - 7 } & No. & \% & No. & \% & No. & \% \\
\hline 0 & 26 & $52 \%$ & 24 & $48 \%$ & 26 & $52 \%$ \\
\hline 1 & 12 & $24 \%$ & 14 & $28 \%$ & 14 & $28 \%$ \\
\hline 2 & 6 & $12 \%$ & 8 & $16 \%$ & 5 & $10 \%$ \\
\hline 3 & 4 & $8 \%$ & 2 & $4 \%$ & 02 & $4 \%$ \\
\hline 4 & 1 & $2 \%$ & 2 & $4 \%$ & 03 & $6 \%$ \\
\hline 5 & 1 & $2 \%$ & 0 & 0 & 0 & 0 \\
\hline Total & 50 & 100.00 & 50 & 100.00 & 50 & 100.00 \\
\hline
\end{tabular}

Table 3: Distribution of cases according to residence.

\begin{tabular}{|l|llllll|}
\hline \multirow{2}{*}{ Residence } & \multicolumn{2}{c}{ Group A } & \multicolumn{2}{c|}{ Group B } & \multicolumn{2}{c|}{ Group C } \\
& No. & \% & No. & \% & No. & \% \\
\hline Rural & 27 & $54 \%$ & 32 & $64 \%$ & 29 & $58 \%$ \\
\hline Urban & 23 & $46 \%$ & 18 & $36 \%$ & 21 & $42 \%$ \\
\hline
\end{tabular}

Table 4: Distribution of cases according to literacy.

\begin{tabular}{|lllllll|}
\hline Education & \multicolumn{2}{c}{ Group A } & \multicolumn{2}{c|}{ Group B } & \multicolumn{2}{c|}{ Group C } \\
status & No. & \% & No. & \% & No. & \% \\
\hline Literate & 20 & $40 \%$ & 19 & $38 \%$ & 17 & $34 \%$ \\
\hline Illiterate & 30 & $60 \%$ & 31 & $62 \%$ & 33 & $66 \%$ \\
\hline
\end{tabular}


Despite our efforts to pick up patients of PIH early in pregnancy, usually patients reported late or did not turn up for admission till late in pregnancy. Hence the maximum no. of patients in all the 3 groups entered the trial between the gestational age of 33-37 weeks of pregnancy.

Table 5: Distribution of cases according to gestational age on admission.

\begin{tabular}{|llllllll|}
\hline $\begin{array}{l}\text { Gestational } \\
\text { Age }\end{array}$ & \multicolumn{2}{c}{ Group A } & \multicolumn{3}{c}{ Group B } & \multicolumn{2}{l|}{ Group C } \\
\hline $\begin{array}{l}27-29 \\
\text { weeks }\end{array}$ & 0 & 0 & 1 & 2.00 & 0 & 0 \\
\hline $\begin{array}{l}29-31 \\
\text { weeks }\end{array}$ & 1 & 2.00 & 2 & 4.00 & 2 & 4.00 \\
\hline $\begin{array}{l}31-33 \\
\text { weeks }\end{array}$ & 2 & 4.00 & 4 & 8.00 & 4 & 8.00 \\
\hline $\begin{array}{l}33-35 \\
\text { weeks }\end{array}$ & 25 & 50.00 & 24 & 48.00 & 20 & 40.00 \\
\hline $\begin{array}{l}35-37 \\
\text { weeks }\end{array}$ & 22 & 44.00 & 19 & 38.00 & 24 & 48.00 \\
\hline Total & 50 & 100.00 & 50 & 100.00 & 50 & 100.00 \\
\hline
\end{tabular}

Table 6: Distribution of cases according to pretreatment - systolic value.

\begin{tabular}{|lllllll|}
\hline \multirow{2}{*}{ Systolic } & \multicolumn{2}{c}{ Group A } & \multicolumn{2}{c|}{ Group B } & \multicolumn{2}{c|}{ Group C } \\
& No. & \% & No. & \% & No. & \% \\
\hline $140-150$ & 20 & $40 \%$ & 17 & $34 \%$ & 24 & $48 \%$ \\
\hline $150-160$ & 13 & $26 \%$ & 19 & $38 \%$ & 15 & $30 \%$ \\
\hline $160-170$ & 11 & $22 \%$ & 11 & $22 \%$ & 11 & $22 \%$ \\
\hline $170-180$ & 6 & $12 \%$ & 3 & $6 \%$ & 0 & 0 \\
\hline Total & 50 & 100.00 & 50 & 100.00 & 50 & 100.00 \\
\hline
\end{tabular}

Table 7: Distribution of cases according to post treatment systolic values.

\begin{tabular}{|lllllll|}
\hline \multirow{2}{*}{ Systolic } & \multicolumn{2}{c}{ Group A } & \multicolumn{2}{c|}{ Group B } & \multicolumn{2}{c|}{ Group C } \\
& No. & $\%$ & No. & $\%$ & No. & \% \\
\hline $110-120$ & 10 & $20 \%$ & 11 & $22 \%$ & 13 & $26 \%$ \\
\hline $120-130$ & 12 & $24 \%$ & 19 & $38 \%$ & 17 & $34 \%$ \\
\hline $130-140$ & 24 & $48 \%$ & 16 & $32 \%$ & 16 & $32 \%$ \\
\hline $140-150$ & 4 & $8 \%$ & 4 & $8 \%$ & 5 & $10 \%$ \\
\hline Total & 50 & 100.00 & 50 & 100.00 & 50 & 100.00 \\
\hline
\end{tabular}

Table 8: Distribution of cases according to pre treatment diastolic values.

\begin{tabular}{|lllllll|}
\hline \multirow{2}{*}{ Diastolic } & \multicolumn{2}{c}{ Group A } & \multicolumn{2}{c|}{ Group B } & \multicolumn{2}{c|}{ Group C } \\
\cline { 2 - 7 } & No. & \% & No. & \% & No. & \% \\
\hline $90-100$ & 10 & $20 \%$ & 10 & $20 \%$ & 15 & $30 \%$ \\
\hline $100-110$ & 23 & $46 \%$ & 26 & $52 \%$ & 29 & $58 \%$ \\
\hline $110-120$ & 17 & $34 \%$ & 14 & $28 \%$ & 6 & $12 \%$ \\
\hline Total & 50 & 100.00 & 50 & 100.00 & 50 & 100.00 \\
\hline
\end{tabular}

Patients were randomly selected and allotted one of the antihypertensive on standard dose. Blood pressure was measured at0, 6, 24, 48 and 72 hours of initiation of therapy. With cases of mild hypertension therapy will be aimed at maintaining the diastolic blood pressure below $85 \mathrm{~mm} \mathrm{Hg}$ and systolic $<130 \mathrm{~mm} \mathrm{Hg}$ so as to prevent complication of hypertension and same time maintaining the vascular perfusion to the fetus. All of the three antihypertensive are equally efficacious in controlling both systolic and diastolic blood pressure. Group BC, $\mathrm{p}<0.05$ there is a greater significant fall in diastolic labetalol group as compared to Methyldopa.

Table 9: Distribution of cases according to post treatment diastolic values.

\begin{tabular}{|lllllll|}
\hline \multirow{2}{*}{ Diastolic } & \multicolumn{2}{c}{ Group A } & \multicolumn{2}{c|}{ Group B } & \multicolumn{2}{l|}{ Group C } \\
& No. & $\%$ & No. & \% & No. & \% \\
\hline $70-80$ & 15 & $30 \%$ & 10 & $20 \%$ & 19 & $38 \%$ \\
\hline $80-90$ & 22 & $44 \%$ & 28 & $56 \%$ & 20 & $40 \%$ \\
\hline $90-100$ & 10 & $20 \%$ & 11 & $22 \%$ & 11 & $22 \%$ \\
\hline $100-110$ & 3 & $6 \%$ & 1 & $2 \%$ & 0 & 0 \\
\hline Total & 50 & 100.00 & 50 & 100.00 & 50 & 100.00 \\
\hline
\end{tabular}

Table 10: Albumin levels in patients prior to starting treatment.

\begin{tabular}{|lllllll|}
\hline \multirow{2}{*}{ Albumin } & \multicolumn{2}{c}{ Group A } & \multicolumn{2}{c|}{ Group B } & \multicolumn{2}{l|}{ Group C } \\
\cline { 2 - 7 } & No. & \% & No. & \% & No. & \% \\
\hline Nil & 18 & $26 \%$ & 22 & $44 \%$ & 24 & $48 \%$ \\
\hline+1 & 21 & $42 \%$ & 23 & $46 \%$ & 19 & $38 \%$ \\
\hline $2+$ & 11 & $22 \%$ & 5 & $10 \%$ & 7 & $14 \%$ \\
\hline Total & 50 & 100.00 & 50 & 100.00 & 50 & 100.00 \\
\hline
\end{tabular}

Table 11: Albumin levels in patients after treatment.

\begin{tabular}{|l|llllll|}
\hline \multirow{2}{*}{ Albumin } & \multicolumn{2}{c}{ Group A } & \multicolumn{2}{c|}{ Group B } & \multicolumn{2}{c|}{ Group C } \\
\cline { 2 - 7 } & No. & $\mathbf{\%}$ & No. & $\mathbf{\%}$ & No. & \% \\
\hline Nil & 41 & $82 \%$ & 43 & $86 \%$ & 38 & $76 \%$ \\
\hline $1+$ & 7 & $14 \%$ & 6 & $12 \%$ & 9 & $18 \%$ \\
\hline $2+$ & 2 & $4 \%$ & 1 & $2 \%$ & 3 & $6 \%$ \\
\hline Total & 50 & 100.00 & 50 & 100.00 & 50 & 100.00 \\
\hline
\end{tabular}

Table 12: Distribution of cases according to Gestational age at delivery.

\begin{tabular}{|lllllll|}
\hline Gestational & \multicolumn{2}{c}{ Group A } & \multicolumn{2}{c|}{ Group B } & \multicolumn{2}{c|}{ Group C } \\
\cline { 2 - 7 } Age & No. & $\%$ & No. & $\%$ & No. & $\%$ \\
\hline $\begin{array}{l}28-31 \\
\text { weeks }\end{array}$ & 0 & 0 & 1 & 2.00 & 1 & 2.00 \\
\hline $\begin{array}{l}31-34 \\
\text { weeks }\end{array}$ & 1 & $2 \%$ & 1 & $2 \%$ & 3 & $6 \%$ \\
\hline $\begin{array}{l}34-37 \\
\text { weeks }\end{array}$ & 13 & $26 \%$ & 14 & $28 \%$ & 11 & $22 \%$ \\
\hline $\begin{array}{l}37-40 \\
\text { weeks }\end{array}$ & 36 & $72 \%$ & 34 & $68 \%$ & 35 & $70 \%$ \\
\hline Total & 49 & 100.00 & 50 & 100.00 & 50 & 100.00 \\
\hline
\end{tabular}


There was significant decrease in proteinuria reported, in Labetalol group than Methyldopa \& nifedipine group.

Table 13: Distribution of cases according to maternal complications.

\begin{tabular}{|c|c|c|c|c|c|c|}
\hline \multirow[t]{2}{*}{ Complications } & \multicolumn{2}{|c|}{ Group A } & \multicolumn{2}{|c|}{ Group B } & \multicolumn{2}{|c|}{ Group C } \\
\hline & No. & $\%$ & No. & $\%$ & No. & $\%$ \\
\hline $\begin{array}{l}\text { Severe } \\
\text { hypertensive } \\
\text { Episodes }\end{array}$ & 2 & $4 \%$ & 1 & $2 \%$ & 4 & $8 \%$ \\
\hline $\begin{array}{l}\text { Placental } \\
\text { abruption }\end{array}$ & 1 & $2 \%$ & 0 & 0 & 1 & $2 \%$ \\
\hline Eclampsia & 0 & 0 & 1 & $2 \%$ & 1 & $2 \%$ \\
\hline Maternal death & 0 & 0 & 0 & 0 & 0 & 0 \\
\hline $\begin{array}{l}\text { Severe } \\
\text { hypotension }\end{array}$ & 02 & $4 \%$ & 0 & 0 & 1 & $2 \%$ \\
\hline
\end{tabular}

The patients who had preterm labour ( $<37$ weeks) were compared in each group and the result was statistically insignificant in between three groups.

Incidences of severe hypertensive episodes were maximum in Methyldopa group. Incidence of placental abruption was nil in labetalol group. Incidences of eclampsias nill in nifedipine group as compared to 1 case in both other groups.

Table 14: Distribution of cases according to mode of delivery.

\begin{tabular}{|lllllll|}
\hline $\begin{array}{l}\text { Mode of } \\
\text { Delivery }\end{array}$ & No. & \% & No. & \% & No. & \% \\
\hline $\begin{array}{l}\text { Normal } \\
\text { vaginal } \\
\text { delivery }\end{array}$ & 36 & $62 \%$ & 40 & $80 \%$ & 37 & $74 \%$ \\
\hline LSCS & 14 & $28 \%$ & 10 & $20 \%$ & 13 & $26 \%$ \\
\hline Total & 50 & 100.00 & 50 & 100.00 & 50 & 100.00 \\
\hline
\end{tabular}

$\begin{array}{ll}\text { Group AC } & \mathrm{P}>0.10 \text { highly insignificant } \\ \text { Group BA } & \mathrm{P}<0.05 \text { highly significant } \\ \text { Group BC } & \mathrm{P}<0.05 \text { highly significant }\end{array}$

Significant results are found on comparing labetalol with nifedipine \& methyldopa. Incidence of LSCS was maximum in Nifedipine study group.

Table 15: Distribution of cases according to foetal outcome.

\begin{tabular}{|lllllll|}
\hline \multirow{2}{*}{ Fetal } & \multicolumn{2}{l}{ Group A } & \multicolumn{2}{l}{ Group B } & \multicolumn{2}{l|}{ Group C } \\
\cline { 2 - 7 } Outcome & No. & \% & No. & \% & No. & $\%$ \\
\hline Preterm & 15 & $30 \%$ & 14 & $28 \%$ & 15 & $30 \%$ \\
\hline Term & 35 & $70 \%$ & 36 & $72 \%$ & 35 & $70 \%$ \\
\hline $\begin{array}{l}\text { Immature } \\
\text { live birth }\end{array}$ & 0 & 0 & 0 & 0 & 0 & 0 \\
\hline Total & 50 & 100.00 & 50 & 100.00 & 50 & 100.00 \\
\hline
\end{tabular}

The present study showed a lower incidence of preterm labour (28\%) in Labetalol group as compared to Methyldopa group.

Table 16: Distribution of cases according to birth weight.

\begin{tabular}{|lcrrrrrr|}
\hline $\begin{array}{l}\text { Foetal Outcome } \\
\text { (Birth Weight) }\end{array}$ & \multicolumn{2}{c}{ Group A } & \multicolumn{3}{c|}{ Group B } & \multicolumn{2}{c|}{ Group C } \\
\hline$<2.5 \mathrm{~kg}$ & 14 & $28 \%$ & \multicolumn{1}{c}{ No. } & \% & No. & \% \\
\hline$\geq 2.5 \mathrm{~kg}$ & 36 & $72 \%$ & 34 & $68 \%$ & 32 & $64 \%$ \\
\hline Total & 50 & 100.00 & 50 & 100.00 & 50 & 100.00 \\
\hline
\end{tabular}

Table 17: Distribution of cases according to perinatal mortality.

\begin{tabular}{|lllllll|}
\hline Perinatal & \multicolumn{2}{c}{ Group A } & \multicolumn{2}{c|}{ Group B } & \multicolumn{2}{c|}{ Group C } \\
Mortality & No. & \% & No. & \% & No. & \% \\
\hline MSB/FSB & 2 & 4.00 & 1 & 2.00 & 1 & 2.00 \\
\hline $\begin{array}{l}\text { Early } \\
\begin{array}{l}\text { Neonatal } \\
\text { death }\end{array}\end{array}$ & 0 & 0 & 1 & 2.00 & 2 & 4.00 \\
\hline Total & 2 & 4.00 & 2 & 4.00 & 3 & 6.00 \\
\hline
\end{tabular}

Table 18: Distribution of cases according to neonatal outcome.

\begin{tabular}{|lllllll|}
\hline Neonatal & \multicolumn{2}{c}{ Group A } & \multicolumn{2}{c|}{ Group B } & \multicolumn{2}{c|}{ Group C } \\
Outcome & No. & $\%$ & No. & \% & No. & \% \\
\hline RDS & 3 & $6 \%$ & 3 & $6 \%$ & 4 & $8 \%$ \\
\hline Jaundice & 2 & $4 \%$ & 2 & $4 \%$ & 2 & $4 \%$ \\
\hline Hypoglycemia & 1 & $2 \%$ & 0 & 0 & 0 & 0 \\
\hline Total & 6 & $12 \%$ & 5 & $10 \%$ & 6 & $12 \%$ \\
\hline
\end{tabular}

\section{DISCUSSION}

PIH complicates only $5-10 \%$ of pregnancies but is Pregnancy induced hypertension (PIH) continues to be major health care related problem in pregnant women even after advancement in the field of medical sciences. The etiology of PIH probably may have relation with background, literacy and economic status of pregnant women. A report states that living in rural area may increase a woman's chance of developing pre-eclampsia.' In another study conducted by Sachdeva et $\mathrm{al}^{10}$ the incidence of PIH was found to be higher in rural women, though the difference was not significant. In our study also majority of cases $(58.6 \%)$ of PIH belong to rural population. Since our hospital is catering a larger rural population; other factors like poverty, unawareness, lack of ante-natal care seeking behaviour and poor availability of health care services in rural areas are also responsible for same. Our study showed that younger age of pregnant women $(66.6 \%)$ might have contributed to a greater frequency of PIH. Another study conducted by Yadav et al ${ }^{11}$ also concluded that the incidence of PIH is greater when the age of pregnant women was less than 25 years. Our study also concluded that primiparous $(50.6 \%)$ are at more risk of developing PIH. Sibai and Cunningham ${ }^{12}$ 
reviewed a number of worldwide studies and concluded that the incidence of pre-eclampsia in nulliparous was more than that for multiparous. Our study concludes that all three antihypertensive drugs- nifedipine, labetalol and methyldopa are equally effective in controlling both systolic and diastolic blood pressure. Although the rate of decreasing urine albumin is highest among the patients giving labetalol. Episode of severe hypertensive crisis was reported in $8 \%$ of cases receiving methyldopa; may be due to slow onset of action. Incidence of LSCS were maximum (28\%) in group of nifedipine. Since it is calcium channel blocker, this mode of action may contribute to this side effect. No statistically difference is noted among the groups regarding the foetal and perinatal outcome.

\section{CONCLUSION}

All three drugs are safe \& effective drug in treatment of PIH. Labetalol is more effective in reducing albuminuria as compared to nifedipine \& methyldopa.

\section{Funding: No funding sources}

Conflict of interest: None declared

Ethical approval: The study was approved by the Institutional Ethics Committee

\section{REFERENCES}

1. Pregnancy hypertension. Cunningham Williams obstetrics. 23rd edition. New York Mc Graw Hill publishing division. 2010:706.

2. Brown MA, Buddle ML, Farrrell T. Randomized trial of management of hypertensive pregnancies by Korotkoff phase 4 or phase 5? Lancet. 1998;352: 777-81.

3. Douglas KA, Redman CWG. Eclampsia in the united Kingdom. Br med J, 1994;309:1395-400.

4. World Health Organization; International collaborative study of hypertensive disorders of pregnancy. Geographic variation in the incidence of hypertension in pregnancy. Am $\mathrm{J}$ obstet gynecol. 1988;158(1):80-3.

5. Crowther CA. Eclampsia at Harare Maternity hospital. An epidemiological study. S Afr med. 1985;68(13):927-9.

6. Bergstrom S, Povey G, Songane F, Ching C. Seasonal incidence of eclampsia and its relationship to meterological data in Mozambique. J perinat Med. 1992;20(2):153-8.

7. Lopez-Jaramillo P, Casas JP, Serrano N. Preeclampsia: from epidemiological observations to molecular mechanisms. Braz J med Biol Res. 2001;34(10):1227-35.

8. Rey E, Lelorier J, Burgers E, Lange IR, Leduc L. Report of the Canadian Society consensus conference:3. Pharmacologic treatment of hypertensive disorders in pregnancy. CMAJ. 1197;157(9):1245-54.

9. American Society of Nephrology; News release, nov.8, 2008. Available from http://www.wrongdiagnosis.com/hd/news/621138.pr egnant-rural-womenmore-at-risk.htm.

10. Sachdeva PD, Patel BG, Bhatt MV. A study of incidence and management of pregnancy induced hypertension in Central Gujrart, India. International Journal of Universal Pharmacy and Life Sciences. 2011;1(3):61-70.

11. Yadav S, Yadav R, Saxena U. Hypertensive disorders of pregnancy and perinatal outcome. J Obset gynecol India. 1997; 17:322-30.

12. Sibai BM, Cunningham FG. Prevention of preeclampsia. In Lindheimer MD, Roberts JM, Cunningham FG editors: Chesley's hypertensive Disorders of Pregnancy. 3rd edition, Elsevier, New York. 2009;215.

Cite this article as: Thakur V, Thakur A, Saroshe S. Comparison of Effect of Nifedipine, Labetalol and Methyldopa in Treatment of Hypertension in Pregnancy in a tertiary care government hospital. Int J Reprod Contracept Obstet Gynecol 2016;5:17-22. 